\title{
Proposed method for agglutinating antibody titer analysis and its use as indicator of acquired immunity in pacu, Piaractus mesopotamicus
}

\author{
Biller-Takahashi, JD. ${ }^{a, b *}$, Montassier, HJ. ${ }^{a}$, Takahashi, LS. ${ }^{c}$ and Urbinati, EC. ${ }^{b}$ \\ aFaculdade de Ciências Agrárias e Veterinárias, Universidade Estadual Paulista - UNESP, \\ Jaboticabal, CEP 14884-900, Jaboticabal, SP, Brazil

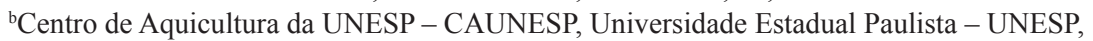 \\ Jaboticabal, CEP 14884-900, Jaboticabal, SP, Brazil \\ ${ }^{\mathrm{c}}$ Faculdade de Zootecnia, Universidade Estadual Paulista - UNESP, CEP 17900-000, Dracena, SP, Brazil \\ *e-mail: jaque.biller@yahoo.com.br
}

Received: October 2, 2012 - Accepted: December 5, 2012 - Distributed: February 28, 2014

(With 1 Figure)

\begin{abstract}
Antibody can be assessed by agglutinating antibody titer which is a quantitative measure of circulating antibodies in serum from fish previously immunized. The antibody evaluation has been performed with different fish species, and is considered a reliable method that can be applied to confirm several hypothesis regarding acquired immunity, even in conjunction with precise methods to describe immune mechanisms. In order to provide appropriate analytical methods for future studies on the specific immune system of native fish, the present study standardized on assay to measure the serum agglutinating antibody titer produced after immunization with inactivated $A$. hydrophila and levamisole administration in pacu. It was possible to determine the agglutinating antibodies titer in a satisfactorily way in pacu immunized with inactive $A$. hydrophila, and the highest titers were observed on fish fed with levamisole.
\end{abstract}

Keywords: fish, methodology, immunology, acquire immunology, humoral immunity.

\section{Aglutinante de anticorpos como indicador de imunidade adquirida de pacu Piaractus mesopotamicus}

\begin{abstract}
Resumo
Os anticorpos podem ser avaliados pelo título aglutinante de anticorpos, que é uma medida quantitativa de anticorpos no soro de peixe previamente imunizados. A determinação do título de anticorpos foi realizada com diversas espécies de peixes e é considerado um método confiável que pode ser aplicado para confirmar diversas hipóteses que envolvam o sistema adquirido de defesa, mesmo em conjunto com métodos precisos, para descrever mecanismos imunes. A fim de prover métodos analíticos adequados para futuros estudos sobre o sistema imune específico de peixes nativos, o presente estudo aperfeiçoou o ensaio para avaliar o título aglutinante de anticorpos em soro de pacu imunizados com A. hydrophila e alimentados com levamisol. Foi possível determinar o título aglutinante de anticorpos de forma satisfatória, em pacus imunizados com $A$. hydrophila inativa, e os maiores títulos foram observados em peixes alimentados com levamisol.
\end{abstract}

Palavras-chave: peixe, metodologia, imunologia, imunidade adquirida, imunidade humoral.

\section{Introduction}

Fish are the most primitive vertebrate group to present acquired immune system, and the ability to produce antibody after antigenic stimuli. Antibodies are glycoproteins classified as immunoglobulins (Ig) that can be expressed in the B lymphocyte membrane or be released by plasma cells (activated B lymphocytes post-connect with antigen) in several body fluids (Solem and Stenvik, 2006). Most of mammals have five classes of immunoglobulins: IgG, $\operatorname{IgM}, \operatorname{IgA}, \operatorname{IgD}$ and $\operatorname{IgE}$, differing in structure and biological activities. However, in fish, the immunoglobulin IgM is the predominant immunoglobulin, and is secreted as a tetrameric form with eight sites for antigen binding. In addition to IgM, some low molecular weight Igs have been found in several fish species (Bogwald et al, 1991; Morrison and Nowak, 2002).

Aquaculture is an important economic activity for many countries, including Brazil. Thus, the development of effective measures to confer a better health status to fishes, such as the improvement of antibacterial or antiviral vaccines or by diet immune modulation can be useful for fish aquaculture (Muiswinkel, 2008). However, the development of these strategies depends on a better understanding of 
fish acquired immune system, particularly the humoral immune responses (Solem and Stenvik, 2006; Vesely et al, 2006). In order to evaluate humoral immunity in fish, the concentrations of IgM in plasma have been usually determined, instead quantifying fish specific anti-antigen antibodies, due to lack of standardized serological techniques, or absence of immune-reagents, mainly for indigenous fish species, like those from our country (Misra et al., 2006). Moreover, it is important to quantify specific IgM antibodies, especially in studies addressing the immune modulation effects of diet components in fishes.

The assessment of agglutinating antibody titer is an easy approach to measure circulating antibodies in serum samples collected from fish previously immunized with particulate antigen preparations (Sugahara and Eguchi, 2012). The agglutination is a clumping reaction between specific antibodies and a particulate antigen, such as erythrocytes or bacterial cells suspension, and it is usually applied in the study of adaptive immune responses to evaluate the antibody production (Plumb and Areechon, 1990; Chen and Light, 1994; Yildirim et al., 2003). In spite of this, there are few studies on antibody immune responses of Brazilian fish species. Therefore, development and standardization of techniques to evaluate the humoral immune responses of native fish is of critical importance for the control of diseases in these species, particularly those used in aquaculture.

Regarding Brazilian native fish, the pacu Piaractus mesopotamicus (Holmberg, 1887) is one of the most significant fish in Brazilian aquaculture. Nevertheless, few studies exist on its immune responses (Abreu et al., 2009; Martins et al., 2009; Sado et al., 2010; Biller-takahashi et al., $2012,2013)$. In order to provide appropriate analytical methods for future studies on the specific immune system of this native Brazilian fish, the present study aimed to standardize and applied the agglutination assay to measure the serum agglutinating antibody titer produced after immunization with inactive vaccine against $A$. hydrophila followed by the administration of the immune modulator levamisole.

\section{Material and Methods}

A total of 120 pacu (P. mesopotamicus) $(218.92 \pm 47.0 \mathrm{~g}$; $21.36 \pm 1.44 \mathrm{~cm})$ was distributed in twelve 1001 tanks (10 fish per tank) with a continuous water flow system and aerated with compressed air diffused through air stones. The water quality parameters were monitored daily and were within the values described for the species (Urbinati et al. 2010): temperature $27.02 \pm 0.89{ }^{\circ} \mathrm{C}$; dissolved oxygen $5.08 \pm 0.49 \mathrm{mg} \mathrm{l}^{-1}$ and $\mathrm{pH} 7.76 \pm 0.07$. Fish remained in these conditions during 20 days for acclimatization, being fed to apparent satiation twice a day with commercial diet ( $28 \%$ protein, $3 \%$ fat, $1 \%$ fiber, levamisole free). The experimental diets were prepared with commercial feed to which were added 0 and $250 \mathrm{mg} . \mathrm{Kg}^{-1}$ of levamisole.

Fish were randomly distributed into tanks and after acclimatization period fish from all treatments have received their experimental diets during seven days. After this period fish from control and levamisole fed groups were immunized with inactive $A$. hydrophila and remained in their aquarium up to 15 days. Subsequent to this period 12 fish per treatment were anesthetized in benzocaine $\left(0.1 \mathrm{~g} \mathrm{~L}^{-1}\right)$ and blood was drawn for serum extraction. Serum was stored at $-70^{\circ} \mathrm{C}$ until use to preserve thermo labile proteins. A sample of whole blood was obtained for haematological determinations.

In order to titer the serum agglutinating antibodies against $A$. hydrophila, a serum agglutination reaction was attempted. The assay was a cell flocculation reaction, in which the antigen consists of stable cells, in this experiment A. hydrophila colony forming units (CFUs) were used, and the result was a visible clumping reaction between particulate and specific antibodies.

Serum of pacu was used to standardize the methodology of agglutinating antibody titer, adapted according to Plumb and Areechon (1990), Chen and Light (1994) and Yildirim et al. (2003). Initially, an Aeromonas hydrophila strain from Laboratório de Patologia de Organismos Aquáticos (LAPOA-CAUNESP-Jaboticabal) (Genbank indetification as ATCC 7966-http://www.ncbi.nlm.nih.gov/ genbank/) was cultured in tryptone soya broth (TSB), at $25^{\circ} \mathrm{C}$, for $24 \mathrm{~h}$ incubation. After this period, the bacterial suspension was washed and centrifuged at $3000 \mathrm{~g}$ (3 min) in sterile phosphate buffer solution (PBS) $(\mathrm{NaCl}, 0.137 \mathrm{M}$; $\mathrm{KCl}, 2.7 \mathrm{mM}$; $\mathrm{KH}_{2} \mathrm{PO}_{4}, 1.5 \mathrm{mM}$; $\mathrm{Na}_{2} \mathrm{HPO}_{4}, 8.1 \mathrm{mM}$; $\mathrm{CaCl}_{2}, 0.9 \mathrm{mM} ; \mathrm{MgCl}_{2}, 0.49 \mathrm{mM}$ in 11 Milli-Q distilled water), with $\mathrm{pH} 7.4$, for three times until complete TSB removal. The bacterial suspension was inactivated with $3 \%$ formalin treatment, washed three times and diluted in sterile PBS. The efficacy of inactivation procedure was performed by culturing the suspension of vaccine. The dilutions were adjusted by turbidity score at $1 \times 10^{9} \mathrm{CFU}$ following Mc Farland scale to adequate the concentration (Vandepitte et al., 1993).

The bacterial suspension was inoculated into the abdominal cavity by intraperitoneal injection. After this procedure, fish were fed commercial diet during 15 days (28\% PB, and 3,000 kcal EB. $\mathrm{kg}^{-1}$, levamisole free), and then sampled and blood was drawn for serum extraction in order to titer the agglutinating antibodies.

The serum agglutinating titer was determined in a 96 -well microtiter plate with round bottom wells. The assay was initiated with a dilution of 1:1 $(50 \mathrm{~mL}$ of phosphate buffer: $50 \mathrm{~mL}$ of serum) and consequently a two-fold serial serum dilutions were made by adding $50 \mathrm{~mL}$ of diluted serum into the remaining wells with $50 \mathrm{~mL}$ of PBS. As a result the serum dilutions were $1 / 2,1 / 4,1 / 8,1 / 16,1 / 32$, $1 / 64,1 / 128,1 / 256,1 / 512,1 / 1024$ and $1 / 2048$. Thereafter, $50 \mathrm{~mL}$ of inactive $A$. hydrophila $\left(1 \times 10^{9} \mathrm{CFUs}\right)$ suspension was added to each well and then micro plates were covered with plastic film and incubated at room temperature for 16-18 h. The agglutination end point was established as the last serum dilution where agglutination was visible. Agglutination antibodies titers were expressed as $\log 2(\mathrm{x}+1)$ of the reciprocal of the highest serum dilution showing 
visible agglutination as compared to the positive control. The last well was used as a negative control, where there were only $50 \mathrm{~mL}$ PBS buffer.

The haematological determinations included the red blood cell, total and differential leukocytes counts were determined in blood smears stained by May-Grünwald-Giemsa (Rosenfeld, 1947). Total leukocytes number was calculated using the formula: leukocytes $/ \mathrm{ml}=$ (leukocyte number in the smear $\mathrm{x}$ erythrocyte number/ml)/2,000 erythrocytes counted in the smear, as described by Ishikawa et al. (2008).

Data were submitted to one-way ANOVA. If results were significant, Tukey test was applied for means comparison. Differences were considered significant at $\mathrm{p}<0.05$ throughout SAS (9.2) statistic program.

\section{Results}

In the present study, the immunization with $A$. hydrophila and administration of $250 \mathrm{mg} \mathrm{kg}^{-1}$ of levamisole for seven days have enhanced the agglutination antibody titer against A. hydrophila (Figure 1). In the Figure 1 the negative control (serum free) has displayed the zero titer once there was no serum, and no agglutination reaction has been observed.

The haematological determinations of immunized pacu have shown an increase in the number of lymphocytes, the responsible cell for antibody production (Table 1). In the Table 1 the augment of lymphocytes is followed by an enhancement of red blood cell (RBC) and leukocytes.

\section{Discussion}

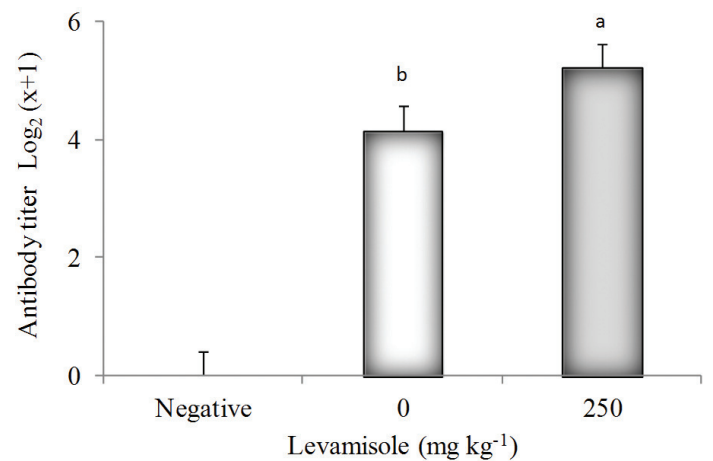

Figure 1. Serum agglutinating antibodies titer against Aeromonas hydrophila of immunized Piaractus mesopotamicus (mean $\pm \mathrm{sd}$ ). Significant differences are indicated by different letters $(\mathrm{p}<0.5)$.
The immunization with $A$. hydrophila, in this study, has been effective in induce a benefic response, such as the increase in antibody titer, since this may protect fish against bacterial disease outbreak. The immunogenic compound used in the vaccine is not pathogenic, but may come from pathogenic microorganisms. In aquaculture, immunization can be an alternative to antibiotics administration, once vaccinated fish became resistant against the inoculated agent (Parslow and Bainton, 2004; Thorarinsson and Powell, 2006).

The increase of antibody concentration found in immunized pacu may protect against disease prompted by $A$. hydrophila, the etiologic agent of an important infectious disease that causes severe outbreaks in Brazilian aquaculture. It is considered a serious economic problem, in addition to the fact that led to the indiscriminate use of antibiotics, which has increased resistance of bacteria to antibiotics worldwide (Vivekanandhan et al., 2002; Vieira, 2003).

The antibody evaluation has been performed with different fish species, and an increase in agglutination titer, as well in this study, has been reported in serum of Oreochromis niloticus challenged with A. hydrophila or immunized with a polyvalent vaccine against $A$. hydrophila, $P$. aeruginosa and E. durans (Bailone et al., 2010). The agglutination titer has supported Sugahara and Eguchi (2012) hypothesis in order to confirm that warm water treatment has influenced on immunization of Plecoglossus altivelis besides the effectiveness of different vaccines. This shows that the agglutination titer is a reliable method and can be applied to confirm several hypothesis regarding acquire immunity, even in conjunction with accurate methods as RT-PCR to characterize immune mechanisms (Takano et al., 2010).

Conversely, fish immune responses can also be influenced by some diet components such as levamisole. The compound included on pacu diet is a synthetic anthelmintic extensively applied in veterinary and human treatments, and has shown a potent immune modulatory action on innate and acquired immune systems of several species, such as Sparus aurata, Salmo salar, Oncorhynchus mykiss and Cyprinus carpio (Siwicki, 1989; Jeney and Anderson, 1993; Mulero et al., 1998; Findlay and Munday, 2000; Cuesta et al., 2002, 2004). Therefore, levamisole has prompt resistance against various etiological agents, such as Vibrio anguillarum, A. hydrophila, Paramoeba sp., Edwardsiella tarda, Photobacterium damselae and nematodes as Anguillicola crassus (Kajita et al., 1990; Geets et al., 1992; Baba et al., 1993; Findlay et al., 2000;

Table 1. Haematological parameters of immunized Piaractus mesopotamicus (mean $\pm \mathrm{sd}$ )*

\begin{tabular}{lcc}
\hline & \multicolumn{3}{c}{ Levamisole $\left.\mathbf{~} \mathbf{m g ~ k g}^{-\mathbf{1}}\right)$} \\
\cline { 2 - 3 } & $\mathbf{0}$ & $\mathbf{2 5 0}$ \\
\hline RBC $\left(10^{6} / \mathrm{mm}^{3}\right)$ & $2.92 \pm 0.34$ a & $3.15 \pm 0.28 \mathrm{a}$ \\
Leukocytes $\left(10^{3} / \mathrm{mm}^{3}\right)$ & $31.42 \pm 15.39 \mathrm{~b}$ & $61.28 \pm 20.89 \mathrm{a}$ \\
Lymphocytes $(\%)$ & $79.82 \pm 4.99 \quad \mathrm{~b}$ & $90.04 \pm 4.11 \mathrm{a}$ \\
\hline
\end{tabular}

*Significant differences are indicated by different letters $(\mathrm{p}<0.5)$. 
Sahoo and Mukherjee, 2002; Leano et al., 2003; Munday and Zilberg, 2003).

As a consequence, several studies have been done to demonstrate the efficacy of immunization and levamisole administration. Jeney and Anderson (1993) have observed in rainbow trout, increase in acquired and innate parameters besides greater protection against $A$. salmonicida. Additionally, Cuesta et al. (2004) have found in vaccinated Sparus aurata elevation in IgM concentration after two weeks of levamisole administration and the effect has persisted for more than six weeks.

The antibody concentration and persistence in serum can differ according to species, age, sexual maturity and physiological events. However the antigen stimulation by artificial immunization or due to chronic infection clearly increases the concentration of circulating antibodies (Hordvik, 2002; Zhao et al., 2008; Jerônimo et al., 2011).

The identification of antibodies produced after immunization by quantitative or qualitative techniques have already been described, including bacterial agglutination, enzyme-linked immunosorbent assay (ELISA), enzymelinked immunospot, Western blotting, viral neutralization and plaque-forming assays. Among the serological tests, the agglutination assay applied is considered quick, simple and inexpensive, in addition to be less prone to generate false reactivity, due to IgM low specificity, multivalence or cross-reactivity (Morrison and Nowak, 2002).

\section{Conclusion}

In conclusion, this study standardized the methodology of agglutinating antibody titer from pacu serum samples, an important Brazilian farmed fish, after A. hydrophila immunization added of levamisole as immune modulator, and could contribute with an appropriate analytical method for future studies on the specific immune system of native Brazilian fish.

Acknowledgments - The authors thank the financial support by CAPES.

\section{References}

ABREU, JS., MARZOCCHI-MACHADO, CM., URBACZEK, AC., FONSECA, LM. and URBINATI, EC., 2009. Leukocytes respiratory burst and lysozyme level in pacu (Piaractus mesopotamicus). Brazilian Journal of Biology, vol. 69, no. 4, p. 1133-9. http:// dx.doi.org/10.1590/S1519-69842009000500018

BABA, T., WATASE, Y. and YOSHINAGA, Y., 1993. Activation of mononuclear phagocyte function by levamisole immersion in carp. Nippon Suisan Gakkaishi, vol. 59, no. 1, p. 301-07.

BAILONE, RL., MARTINS, ML., MOURIÑO, JLP., VIEIRA, FN., PEDROTTI, FS., NUNES, GC. and SILVA, BC., 2010. Hematology and agglutination titer after polyvalent immunization and subsequent challenge with Aeromonas hydrophila in Nile tilapia (Oreochromis niloticus). Archivos de Medicina Veterinaria, vol. 42 , no. 3, p. 221-7.

BILLER-TAKAHASHI, JD., TAKAHASHI, LS., MARZOCCHIMACHADO, CM., ZANUZZO, FS., SABIONI, RE. and URBINATI,
EC., 2012. Hemolytic activity of alternative complement system as an indicator of innate immunity in pacu (Piaractus mesopotamicus). Revista Brasileira de Zootecnia, vol. 41, no. 2, p. 237-41. http:// dx.doi.org/10.1590/S1516-35982012000200001

BILLER-TAKAHASHI, JD., TAKAHASHI, LS., SAITA, MV., GIMBO, RY. and URBINATI, EC., 2013. Leukocytes respiratory burst activity as indicator of innate immunity of pacu Piaractus mesopotamicus. Brazilian Journal of Biology, vol. 73, no. 2, p. 425-429. http://dx.doi.org/10.1590/S1519-69842013000200026

BOGWALD, J., STENSVAG, K., HOFFMAN, J. and JORGENSEN, T., 1991. Antibody specificities in Atlantic salmon, Salmo salar L., against the fish pathogens Vibrio salmonicida and Vibrio anguillarum. Journal of Fish Disease, vol. 14, no. 1, p. 79-87. http://dx.doi.org/10.1111/j.1365-2761.1991.tb00578.x

CHEN, MF. and LIGHT, TS., 1994. Specificity of the channel catfish antibody to Edwardsiella ictaluri. Journal of Aquatic Animal Health, vol. 6, no. 3, p. 226-70. http://dx.doi.org/10.1577/15488667(1994)006<0266:CSOTCC $>2.3 . \mathrm{CO} ; 2$

CUESTA, A., MESEGUER, J. and ESTEBAN, M.A., 2002. Levamisole is a potent enhancer of gilthead sea bream natural cytotoxic activity. Veterinary Immunology and Immunopathology, vol. 89, no. 3-4, p. 169-74. http://dx.doi.org/10.1016/S01652427(02)00220-9

CUESTA, A., MESEGUER, J. and ESTEBAN, M.A., 2004. Total serum immunoglobulin $\mathrm{M}$ are affected by immunomodulators in sea bream (Sparus aurata L.). Veterinary Immunology and Immunopathology, vol. 101, no. 3-4, p. 203-10. http://dx.doi. $\operatorname{org} / 10.1016 /$ j.vetimm.2004.04.021

FINDLAY, V.L. and MUNDAY, B.L., 2000. The immunomodulatory effects of levamisole on the non-specific immune system of Atlantic salmon, Salmo salar L. Journal of Fish Disease, vol. 23, no. 6, p. 369-78. http://dx.doi.org/10.1046/j.1365-2761.2000.00231.x

FINDLAY, V.L., ZILBERG, D. and MUNDAY, B.L., 2000. Evaluation of levamisole as a treatment for amoebic gill disease of Atlantic salmon, Salmo salar L. Journal of Fish Disease, vol. 23, no. 3, p. 193-8. http://dx.doi.org/10.1046/j.13652761.2000.00238.x

GEETS, A., LIEWES, E.W. and OLLEVIER, F., 1992. Efficacy of some antihelminthics against the swimbladder nematode Anguillicola crassus of eel Anguilla anguilla under saltwater conditions. Disease of Aquatic Organism, vol. 13, no. 1, p. 123-8.

HORDVIK, I., 2002. Identification of a novel immunoglobulin d transcript and comparative analysis of the genes encoding $\operatorname{IgD}$ in Atlantic salmon and Atlantic halibut. Molecular and Immunology, vol. 39 , no. 1 , p. 80-5.

ISHIKAWA. NM., RANZANI-PAIVA, M JT. and LOMBARDI, JV., 2008. Metodologia para quantificação de leucócitos totais em peixes, Oreochromis niloticus. Archives of Veterinary Science, vol. 13 , no. 1 , p. 54-63.

JENEY, G. and ANDERSON, DP., 1993. Glucan injection or bath exposure given alone or in combination with a bacterin enhance the non-specific defense mechanisms in rainbow trout (Oncorhynchus mykiss). Aquaculture, vol. 116, no. 4, p. 315-29.

JERÔNIMO, GT., LAFFITTE, LV., SPECK, GM. and MARTINS, ML., 2011. Seasonal influence on the hematological parameters in cultured Nile tilapia from southern Brazil. Brazilian Journal of Biology, vol. 71, no. 3, p. 719-25. http://dx.doi.org/10.1590/ S1519-69842011000400017 
KAJITA, Y., SAKAI, M., ATSUTA, S. and KOBAYASH, M., 1990. The immunomodulatory effects of levamisole on rainbow trout, Oncorhynchus mykiss. Fish Pathology, vol. 25, no. 2, p. 93-8.

LEANO, E.M., GUO, J., CHANG, S. and LIAO, I.C., 2003. Levamisole enhances non-specific immune response of cobia (Rachycentron canadum) fingerlings. Journal of Fish Society of Taiwan, vol. 30, no. 4, p. 321-30

MARTINS, ML., MYIAZAKI, DMY., TAVARES-DIAS, M., FENERICK-JR. J., ONAKA, EM., BOZZO, FR., FUJIMOTO, RY. and MORAES, FR., 2009. Characterization of the acute inflammatory response in the hybrid tambacu (Piaractus mesopotamicus male $\times$ Colossoma macropomum female) (Osteichthyes). Brazilian Journal of Biology, vol. 69, no. 3, p. 957-62.

MISRA, CK., DAS, BK., MUKHERJEE, SC. and PATTNAIK, P., 2006. Effect of multiple injections of b-glucan on non-specific immune response and disease resistance in Labeo rohita fingerlings. Fish and Shellfish Immunology, vol. 20, no. 3, p. 305-19.

MORRISON, RN. and NOWAK, BF., 2002. The antibody response of teleost fish. Seminars in Avian and Exotic Pet Medicine, vol. 11, no. 1, p. 46-54. http://dx.doi.org/10.1053/saep.2002.28241

MUISWINKEL, WBV., 2008. A history of fish immunology and vaccination I. The early days. Fish and Shellfish Immunology, vol. 25, no. 4, p. 397-408. http://dx.doi.org/10.1016/j.fsi.2008.02.019

MULERO, V., ESTEBAN, MA., MUNOZ, J. and MESEGUER, J., 1998. Dietary intake of levamisole enhances the immune response and disease resistance of the marine teleost gilthead seabream (Sparus auratus L.). Fish and Shellfish Immunology, vol. 8, no. 1, p. 49-62. http://dx.doi.org/10.1006/fsim.1997.0119

MUNDAY, B. and ZILBERG, D., 2003. Efficacy of, and toxicity associated with, the use of levamisole in seawater to treat amoebic gill disease. Bulletin Archive - European Association of Fish Pathologists, vol. 23, no. 1, p. 3-6.

PARSLOW, TG. and BAINTON, DF., 2004. Imunidade inata. In PASLOW,TG., STITES, DP., TERR, AI., IMBODEN, JB. (Eds.) Imunologia médica. Rio de Janeiro: Guanabara Koogan. p. 16-33.

PLUMB, JA. and AREECHON, N., 1990. Effect of malathion on humoral immune response of channel catfish. Developmental and Comparative Immunology, vol. 14, no. 3, p. 355-8.

ROSENFELD, G., 1947. Corante pancrômico para hematologia e citologia clínica. Nova combinação dos componentes do May-Grünwald e do Giemsa num só corante de emprego rápido. Memórias do Instituto Butantan, vol. 20, no. 1, p. 329-34.

SADO, RY., BICUDO, AJA. and CYRINO, JEP., 2010. Dietary levamisole influenced hematological parameters of juvenile pacu, Piaractus mesopotamicus (Holmberg 1887). Journal of World Aquaculture Society, vol. 41, no. 1, p. 66-75. http://dx.doi. org/10.1111/j.1749-7345.2009.00334.x

SAHOO, PK. and MUKHERJEE, SC., 2002. The effect of dietary immunomodulation upon Edwardsiella tarda vaccination in healthy and immunocompromised Indian major carp (Labeo rohita). Fish and Shellfish Immunology, vol. 12, no. 1, p. 1-16. http://dx.doi.org/10.1006/fsim.2001.0349
SIWICKI, AK., 1989. Immunostimulating influence of levamisole on nonspecific immunity in carp (Cyprinus carpio). Developmental and Comparative Immunology, vol. 13, no. 1, p. 87-91.

SOLEM, ST. and STENVIK, J., 2006. Antibody repertoire development in teleosts - a review with emphasis on salmonids and Gadus morhua L. Developmental and Comparative Immunology, vol. 30, no. 1-2, p. 57-76. http://dx.doi.org/10.1016/j.dci.2005.06.007

SUGAHARA, K. and EGUCHI, M., 2012. The use of warmed water treatment to induce protective immunity against the bacterial cold-water disease pathogen Flavobacterium psychrophilum in ayu (Plecoglossus altivelis). Fish and Shellfish Immunology, vol. 32, no. 3, p. 489-93.

TAKANO, T., MATSUYAMA, T., OSEKO, N., SAKAI, T., KAMAISHI, T., NAKAYASU, C., SANO, M. and IIDA, T., 2010. The efficacy of five avirulent Edwardsiella tarda strains in a live vaccine against Edwardsiellosis in Japanese flounder, Paralichthys olivaceus. Fish and Shellfish Immunology, vol. 29, no. 4, p. 687-93. http://dx.doi.org/10.1016/j.fsi.2010.07.012

THORARINSSON, R. and POWELL, DB., 2006. Effects of disease risk, vaccine efficacy, and market price on the economics of fish vaccination. Aquaculture, vol. 256, no. 1-4, p. 42-49. http://dx.doi.org/10.1016/j.aquaculture.2006.01.033

URBINATI, EC., GONÇALVES, FD. and TAKAHASHI, LS., 2010. Pacu (Piaractus mesopotamicus). In BALDISSEROTO, B. and GOMES, LC. (Ed.). Espécies nativas para piscicultura no Brasil. 2nd ed. Santa Maria: Editora UFSM. p. 225-246.

VANDEPITTE, J., ENGBAEK, K. and PIOT, P., 1993. Métodos básicos de laboratório em bacteriologia clínica. Genebra: Organização Mundial de Saúde. 122p.

VESELY, T., RESCHOVA, S., POKOROVA, D., HULOVA, J. and NEVORANKOVA, Z., 2006. Production of monoclonal antibodies against immunoglobulin heavy chain in common carp (Cyprinus carpio L.). Veterinarni Medicina, vol. 51, no. 5, p. 296-302.

VIEIRA, RHSF., 2003. Microbiologia, higiene e qualidade do Pescado. São Paulo: Livraria Varella. p. 380.

VIVEKANANDHAN, G., SAVITHAMANI, K., HATHA, AAM. and LAKSHMANAPERUMALSAMY, P., 2002. Antibiotic resistance of Aeromonas hydrophila isolated from marked fish and prawn of South India. International Journal of Food Microbiology, vol. 76, no. 1, p. 165-8. http://dx.doi.org/10.1016/ S0168-1605(01)00638-9

YILDIRIM, M., LIM, C., WAN, PJ. and KLESIUS, PH., 2003. Growth performance and immune response of channel catfish (Ictalurus puctatus) fed diets containing graded levels of gossypolacetic acid. Aquaculture, vol. 219, no. 1, p. 751-68. http://dx.doi. org/10.1016/S0044-8486(03)00062-0

ZHAO, X., FINDLY, RC. and DICKERSON, HW., 2008. Cutaneous antibody-secreting cells and B cells in a teleost fish. Developmental and Comparative Immunology, vol. 32, no. 5, p. 500-8. 